\title{
AVIAN INFLUENZA VIRUS AND NEWCASTLE VIRUS SURVEILLANCE AND CHARACTERIZATION IN BROILER AND LAYER CHICKEN FLOCKS IN EGYPT
}

\author{
AZHAR G. SHALABY*; AHMED M. ERFAN*; FATMA A. ABDEL REHEEM*; ABDULLAH A. \\ SELIM $^{* *}$; MOHAMED H. AL HUSSENY ${ }^{* * * *}$; SHEREEN G. KHOLOSY ${ }^{* * *}$ and SOAD A. NASEF ${ }^{* *}$ \\ *Biotechnology Department, Reference Laboratory for Veterinary Quality Control on Poultry Production, Animal Health Research Institute, \\ Nadi El-Seid St., P.O. Box 246, Dokki, Giza 12618, Egypt. \\ ${ }^{* *}$ Poultry Diseases Department, Reference Laboratory for Veterinary Quality Control on Poultry Production, Animal Health Research \\ Institute, Nadi El-Seid St., P.O. Box 246, Dokki, Giza 12618, Egypt. \\ ${ }^{* * *}$ Epidemiology Department, Reference Laboratory for Veterinary Quality Control on Poultry Production, Animal Health Research Institute, \\ Nadi El-Seid St., P.O. Box 246, Dokki, Giza 12618, Egypt. \\ ${ }^{* * * *}$ Biochemistry Department. Reference Laboratory for Veterinary Quality Control on Poultry Production, Animal Health Research \\ Institute, Nadi El-Seid St., P.O. Box 246, Dokki, Giza 12618, Egypt.
}

Email: azhar_gaber@yahoo.com

\section{ABSTRACT}

Received at: 16/6/2014

Considering that highly pathogenic avian influenza H5N1 endemically circulates in the Egyptian poultry population, Active surveillance was undertaken in 195 broiler and layers farms from Eighteen Egyptian governorates resulted in, 34,7 and 24 positive farms for AI H9N2, AI H5N1 and Virulent ND respectively, using RT-PCR.

Accepted: 6/8/2014 The genetic analysis of avian influenza viruses of HA gene of the H5N1 type revealed that these viruses are highly pathogenic strains as they are tracking clade 2.2.1 of classic viruses which became endemic in Egypt since 2006. However, H9N2 viruses revealed that they are low pathogenic as they are tracking G1-lineage of Asian viruses which transmitted to Middle East scince 2000. Also sequence analysis for $\mathrm{F}$ gene for twelve NDV isolates revealed that they are of virulent type and genetically related to genotype VII NDV except two isolates are avirulent type and resemble Lasota- like- strains. Pathogenecity studies for NDV isolates using ICPI was evaluated for the strain (NDV-EG-567f-2012) which of virulent with ICPI value 1.96. The analysis of isolated strains by different diagnostic and analytical techniques implies that the H5N1 and H9N2 silent infection exist in Egypt.

Key words: Pathogenisity-Lasota like strains- lineage- RT_PCR-endemic.

\section{INTRODUCTION}

The highly pathogenic avian influenza virus subtype $\mathrm{H} 5 \mathrm{~N} 1$ was first recognized in poultry in Egypt in 2006 (Aly et al., 2008). The subtype H9N2 is widely circulated in the Middle East region and it was associated with serious disease in poultry (Aamir et al., 2007; Alexander, 2007; Perk et al., 2009). In addition, recent detection of low pathogenic avian influenza H9N2 subtype has been recorded in bobwhite quail in Egypt in 2011 with genetic relatedness to the G1-lineage that represented by A/Quail/Hong Kong/G1/97 (Qa/HK/G1/97) that still circulated in the Middle East region. (El-Zoghby et al., 2012) Standard RT-PCR has been applied previously to the detection of AIV and each of the 15 HA subtypes (Starick et al., 2000; Lee et al., 2001; Munch et al., 2001). Sequence analysis of the viral genes and their respective amino acids is a valuable tool for detection of any genic variation among viruses circulating in the field and also provides information about the source of the initial disease outbreak in a certain geographic district (Duvvvuri et al., 2009). The broad variation in virulence and clinical signs necessitates the careful definition of what constitutes ND for the purposes of trade, control measures and policies. The definition of ND currently in use in all member states of the European Union is defined in Directive 92/66/EEC of the Commission for European Communities (OIE 2012). ND outbreaks occur frequently in Egypt and the source of the virulent NDV in these outbreaks are not known. (Mohamed et al., 2009) reported the complete genome sequence of a NDV strain isolated from an outbreak at a poultry farm in Al-Sharkia province, Egypt in 2005 (chicken/Egypt/1/2005).

In this work, the surveillance were carried out to detect the avian influenza and Newcastle viruses and evaluate their virulence attitude as considered most important respiratory viruses for poultry and specially broiler and layer sectors and its zoonotic 
picture. Furthermore discuss the genetic characterizations for Newcastle and AI with its subtypes H5N1 and H9N2.

\section{MATERIALS and METHODS}

195 layer and broiler farms' from eighteen Egyptian governorates have been survived during late of 20112012. 2448 cloacal swabs and 306 organs like trachrea and lung were collected and examined as shown in Table. (1).

Table 1: Collective Numbers of farms, samples in relation to governorate and type of production.

\begin{tabular}{|c|c|c|c|c|c|c|}
\hline \multirow[b]{2}{*}{ No. } & \multirow[b]{2}{*}{ Governorates } & \multirow{2}{*}{$\begin{array}{l}\text { No. of } \\
\text { farms }\end{array}$} & \multicolumn{2}{|c|}{ No of examined samples } & \multicolumn{2}{|c|}{ Type of production } \\
\hline & & & $\begin{array}{c}\text { Cloacal } \\
\text { swabs }\end{array}$ & $\begin{array}{c}\text { Organs } \\
\text { (Tr\& lung) }\end{array}$ & Layers & Broilers \\
\hline 1 & Al Fayoum & 51 & 920 & 65 & 5 & 46 \\
\hline 2 & Al Qalubia & 20 & 150 & 14 & 1 & 19 \\
\hline 3 & Al Dakahlia & 19 & 294 & 34 & 3 & 16 \\
\hline 4 & Al Ismalia & 18 & 85 & 22 & 0 & 18 \\
\hline 5 & Benisueif & 15 & 204 & 26 & 3 & 12 \\
\hline 6 & Domiatte & 11 & 95 & 47 & 2 & 9 \\
\hline 7 & Luxor & 12 & 22 & 9 & 0 & 12 \\
\hline 8 & Al Giza & 9 & 186 & 10 & 4 & 5 \\
\hline 9 & Al Sharkia & 10 & 180 & 8 & 3 & 7 \\
\hline 10 & Al Alexandria & 8 & 90 & 26 & 4 & 4 \\
\hline 11 & Kafr el sheikh & 5 & 46 & 10 & 0 & 5 \\
\hline 12 & Al Behira & 5 & 64 & 11 & 0 & 5 \\
\hline 13 & Al Monefia & 3 & 44 & 2 & 0 & 3 \\
\hline 14 & Al Gharbia & 3 & 20 & 11 & 0 & 3 \\
\hline 15 & Al Minia & 2 & 38 & 2 & 0 & 2 \\
\hline 16 & North sinai & 2 & 4 & 6 & 0 & 2 \\
\hline 17 & Aswan & 1 & - & 1 & 0 & 1 \\
\hline \multirow[t]{2}{*}{18} & Port said & 1 & 6 & 1 & 0 & 1 \\
\hline & Total & 195 & 2448 & 306 & 25 & 170 \\
\hline
\end{tabular}

\section{Real time PCR:}

This test was done for the different samples to detect the AI common gene and haemagglutinin genes of H5 and H9 by multiplex PCR also the method was done to detect the $\mathrm{F}$ gene for Newcastle and determine the virulence of the positive strain.

RNA was extracted from samples was performed using the QIAamp viral RNA Mini kit (Qiagen, Germany, GmbH) according to the manufacturer's recommendations. Briefly $140 \mu \mathrm{l}$ of the sample suspension was incubated with $5.6 \mu \mathrm{l}$ of carrier RNA and $560 \mu \mathrm{l}$ of AVL buffer at room temperature for 10 min. After incubation, $560 \mu \mathrm{l}$ of $100 \%$ ethanol was added to the lysate. The mixture was then transferred to the silica column then centrifuged and washed following the manufacturer's recommendations. Nucleic acid was eluted with $60 \mu$ of elution buffer (AE) provided within the kit] NDV, and AI: Primers were utilized in a $25-\mu 1$ reaction containing $12.5 \mu \mathrm{l}$ of Quantitect probe rt-PCR master mix (Qiagen, Germany, GmbH), $0.5 \mu \mathrm{f}$ each primer of $50 \mathrm{pmol}$ concentration, $0.125 \mu \mathrm{l}$ of the specific probe, $4.5 \mu \mathrm{l}$ of water, $0.25 \mu \mathrm{l}$ of the rt-enzyme and $6 \mu \mathrm{l}$ of RNA extract.. The reaction was performed in a Stratagen MX3005P real time PCR machine (Stratagene, USA). Oligonucleitide primers are described as in Table (2). 
Assiut Vet. Med. J. Vol. 60 No. 142 July 2014

Table 2: RT- PCR primers used in this study were supplied from Metabion (Germany).

\begin{tabular}{|c|c|c|c|}
\hline RNA Virus & Gene & $\begin{array}{c}\text { Primer/ probe sequence } \\
5^{\prime}-3^{\prime}\end{array}$ & Ref. \\
\hline \multirow[t]{18}{*}{ AI } & Matrix & Sep1 & Slomoka et al. 2007 \\
\hline & & AGATGAGTCTTCTAA CCGAGGTCG & \\
\hline & & Sep 2 & \\
\hline & & TGCAAAAACATCTTC AAGTCTCTG & \\
\hline & & SEPRO & \\
\hline & & [FAM]TCAGGCCCC CTCAAAGCCGA [TAMRA] & \\
\hline & H5 & H5LH1 & \\
\hline & & ACATATGACTAC CCACARTATTCA G & \\
\hline & & H5RH1 & \\
\hline & & AGACCAGCT AYC ATGATTGC & \\
\hline & & H5PRO & \\
\hline & & [FAM]TCWACA GTGGCGAGT TCCCTAGCA[TAMRA] & \\
\hline & H9 & H9F & Ben Shabat et al. \\
\hline & & GGAAGAATTAATTATTATTGGTCGGTAC & 2010 \\
\hline & & H9R & \\
\hline & & GCCACCTTTTTCAGTCTGACATT & \\
\hline & & H9 Probe & \\
\hline & & [FAM]AACCAGGCCAGACATTGCGAGTAAGATCC[TAMRA] & \\
\hline \multirow[t]{9}{*}{ ND } & Vir & F+4839 TCCGGAGGATACAAGGGTCT & Wise et al. 2004 \\
\hline & & F-4939 AGCTGTTGCAACCCCAAG & \\
\hline & & F+4894 [FAM]AAGCGTTTCTGTCTCCTTCCTCCA[TAMRA] & \\
\hline & Matrix & M_4100 & \\
\hline & & 5_-AGTGATGTGCTCGGACCTTC-3_ & \\
\hline & & M_4169 & \\
\hline & & 5_-[FAM]TTCTCTAGCAGTGGGACAGCCTGC[TAMRA]-3_ & \\
\hline & & M_4220 & \\
\hline & & 5_-CCTGAGGAGAGGCATTTGCTA-3 & \\
\hline
\end{tabular}

\section{Virus isolation:}

The positive PCR samples were directed to virus isolation according to OIE 2008. Also virulence test evaluation for low pathogenic avian influenza virus (H9N2) and Newcastle virus. Depending on OIE 2012.

I: Pathogenicity of H9N2 virulence: protocol using 8 weeks SPF chicken. Virulence was evaluated for randomly selected two isolates:

II: Pathogenicity of NDV virulence: was done by injecting the virus in SPF day old chicks using ICPI.
Genotyping of isolates: sequencing for 20 positive isolates. It was performed by purification of PCR

products using QIAquick PCR Product extraction kit. (Qiagen, Valencia). The sequence reaction was done using Bigdye Terminator V3.1 cycle sequencing kit (Perkin-Elmer) and the sequence reaction was purified using Centrisep spin column (ABI, USA). DNA sequences were obtained using Applied Biosystems 3130 genetic analyzer (ABI, USA). A phylogenetic tree was created by the MegAlign module of Lasergene DNAStar.

The sequencing method was done for HA gene of AI virus and for $\mathrm{F}$ gene of Newcastle virus. 


\section{RESULTS}

A total 41 farms out of 195 examined are positive for AIV with a percentage of $21 \%$, It appeared that 34 farm were positive for AI H9 with a percentage $83 \%$ and 7 farms were positive for AI H5 with a percentage of $17 \%$ Also 41 farms were positive for matrix gene of Newcastle virus with a percentage of $21 \%$, Twenty four farms were positive for the virulent strain of Newcastle with a percentage of $58.5 \%$.

Table 3: The results of PCR test for the examined Avian influenza and Newcastle viruses in relation to each governorate.

\begin{tabular}{|c|c|c|c|c|c|c|}
\hline \multirow{3}{*}{ Gov. } & \multirow{3}{*}{$\begin{array}{c}\text { No of examined } \\
\text { farms }\end{array}$} & \multirow{3}{*}{$\begin{array}{c}\text { AI } \\
\text { Matrix }\end{array}$} & \multicolumn{4}{|c|}{ The PCR results } \\
\hline & & & \multirow{2}{*}{ AIH9 } & \multirow{2}{*}{ AI H5 } & \multicolumn{2}{|c|}{ ND } \\
\hline & & & & & Matrix ND & vNDV \\
\hline 1- Faioum & 51 & 15 & 14 & 1 & 12 & 7 \\
\hline 2- Qalioubia & 20 & 7 & 6 & 1 & 4 & 2 \\
\hline 3- Dakahli & 19 & 2 & 2 & 0 & 3 & 3 \\
\hline 4- Ismalia & 18 & 0 & 0 & 0 & 3 & 2 \\
\hline 5- Benisueif & 15 & 4 & 2 & 2 & 0 & 0 \\
\hline 6- Domiatt & 11 & 0 & 0 & 0 & 1 & 0 \\
\hline 7- Luxor & 12 & 2 & 1 & 1 & 1 & 0 \\
\hline 8- Giza & 9 & 0 & 0 & 0 & 2 & 2 \\
\hline 9- Sharkia & 10 & 3 & 1 & 2 & 3 & 1 \\
\hline 10- Alexandria & 8 & 3 & 3 & 0 & 7 & 4 \\
\hline $\begin{array}{l}\text { 11- Kafr el } \\
\text { sheikh }\end{array}$ & 5 & 1 & 1 & 0 & 3 & 2 \\
\hline 12- Behira & 5 & 1 & 1 & 0 & 1 & 0 \\
\hline 13- Monefia & 3 & 1 & 1 & 0 & 0 & 0 \\
\hline 14- Gharbia & 3 & 1 & 1 & 0 & 0 & 0 \\
\hline 15- Minia & 2 & 1 & 1 & 0 & 0 & 0 \\
\hline 16- North Sinai & 2 & 0 & 0 & 0 & 0 & 0 \\
\hline 17- Aswan & 1 & 0 & 0 & 0 & 0 & 0 \\
\hline 18- Port said & 1 & 0 & 0 & 0 & 1 & 1 \\
\hline Total & \multirow{3}{*}{195} & 41 & 34 & 7 & 41 & 24 \\
\hline \multirow{2}{*}{ Incidence rate } & & $21 \%$ & $17.4 \% *$ & $3.5 \% *$ & $21 \%$ & $12 \% *$ \\
\hline & & & $83 \% * *$ & $17 \% * *$ & & $58.5 \% * *$ \\
\hline
\end{tabular}

Note: * the percent in relation to No of examined samples

** the percent in relation to the positive farms.

Virulence evaluation for different viruses:

I: evaluation of $\mathrm{H} 9 \mathrm{~N} 2$ virulence:

Virulence was evaluated for (2) isolates:

1-A/Chicken/Egypt/114940v/NLQP/2011/H9N2.

2-A/Chicken/Egypt/114922v/NLQP/2011/H9N2.

The results showed that the viruses that have been tested were low pathogenic.

II: virulence evaluation of isolated NDVs:

Using ICPI showed that, all evaluated viruses (NDVEG-567f-2012) were virulent strains (ICPI=1.96).

\section{Sequence analysis:}

The genetic analysis for 4 strains of avian influenza viruses HA gene of the H5N1 type [A/chicken/Egypt/128s/2012, A/chicken/Egypt/12186F-9/2012,

A/chicken/Egypt/12186F-12/2012 and $\mathrm{A} /$ chicken/Egypt/125s/2012] revealed that these viruses are highly pathogenic as well as tracking clade 2.2.1 virus which is endemic and widespread in Egypt since 2006 and no cases of Egyptian H5N1 variant strain which follows clade 2.2.1.1 and described in Table (4). 
The genetic analysis of HA gene of 4 isolates of H9N2 revealed that they are of low pathogenic in the phylogenic tree they are tracking G1-lineage of Asian viruses which spread at Middle East and they are nearly similar to other Egyptian viruses from 2011 (Fig.2).

The genetic analysis of $\mathrm{F}$ gene of 12 selected isolates of NDV revealed that ten strains are virulent genotype VII) and also the recent isolated strains from Middle East like Jordan (apmv1/chicken/Jordan/Jo 11/2011) and Israel (buzzard/Israel/714/2011) with a percentage of $99.98 \%$ while not similar to vaccinal strains as lasota with a percentage of $72 \%$ based on partial $\mathrm{F}$ gene. As well as 2 isolates of NDV were classified as avirulent that like vaccinal strain (Lasota - like NDV (lentogenic strain), (Fig.3).

Table 4: No. and type of isolates of each virus.

\begin{tabular}{|c|c|c|c|}
\hline Virus & \multicolumn{2}{|c|}{ Genotype } & No. of cases \\
\hline H5N1 & Classic A & Clade 2.2.1 & 4 \\
\hline \multirow{2}{*}{ NDV } & Virulent & Vir VII & $\overline{10}$ \\
\hline & \multicolumn{2}{|c|}{ Avirulent } & 2 \\
\hline H9N2 & Low pathogenic & Asian $\mathrm{G} /$ lineage & 4 \\
\hline
\end{tabular}

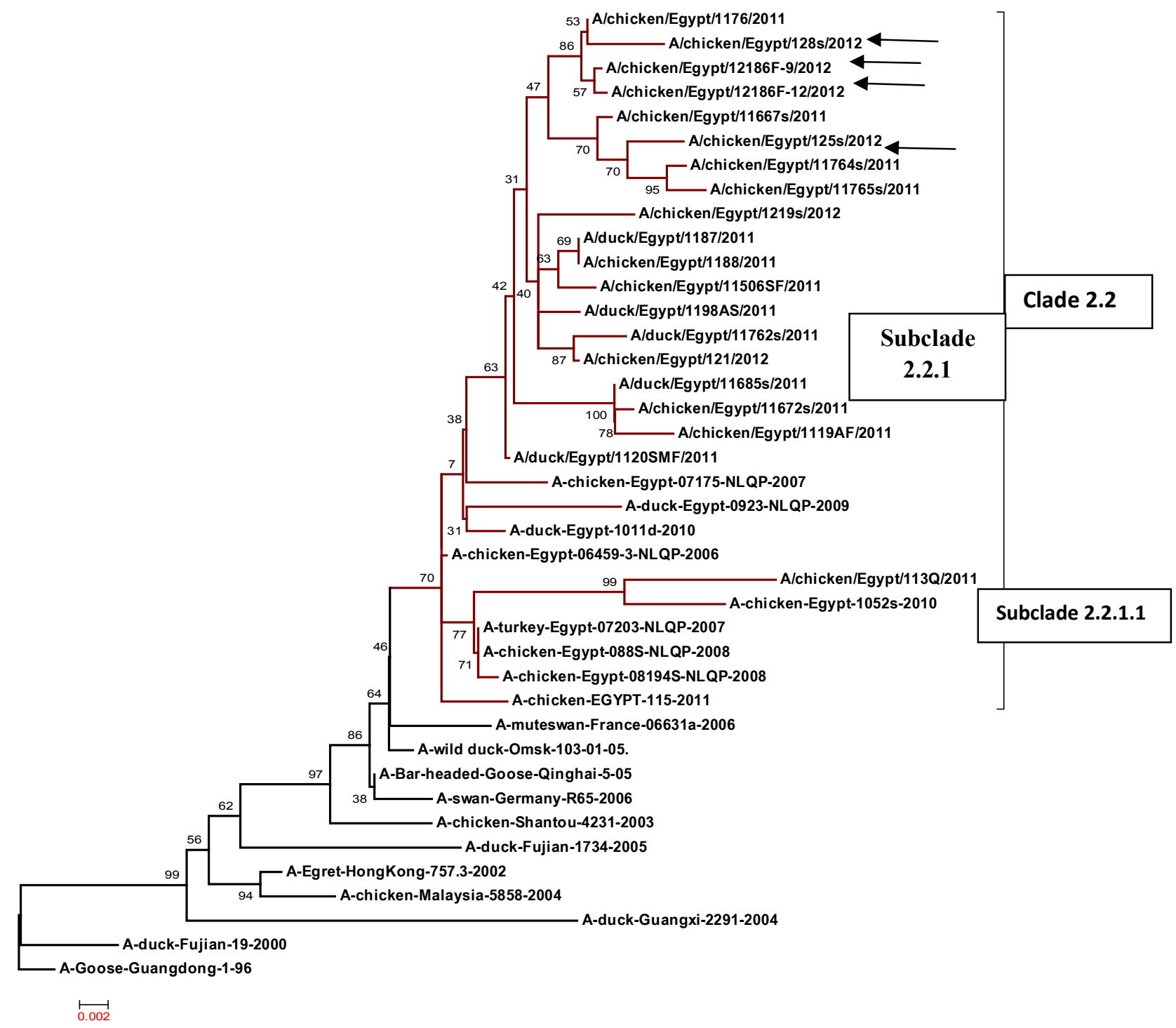

(Fig. 1): Phylogenetic analysis of HA gene of the Egyptian H5N1 isolates in comparison to other strains from Middle East region, Asian and other strains.

*Note: Black arrows refer to the sequenced strains in this study. 


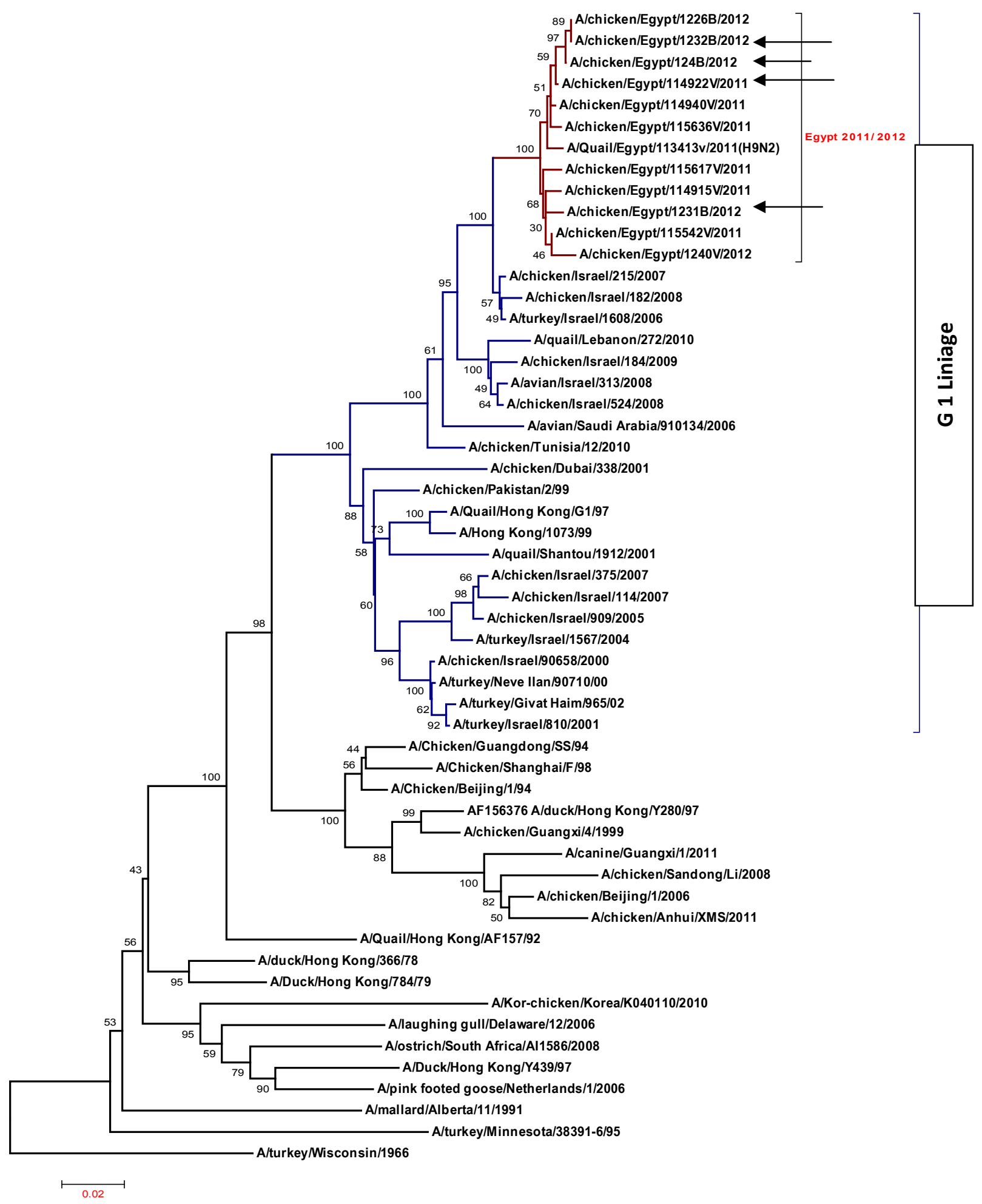

(Fig. 2): Phylogenetic analysis of HA gene of the Egyptian H9N2 isolates in comparison to other strains from Middle East region, Asian and other strains.

*Note : Black arrows refer to the sequenced strains in this study. 


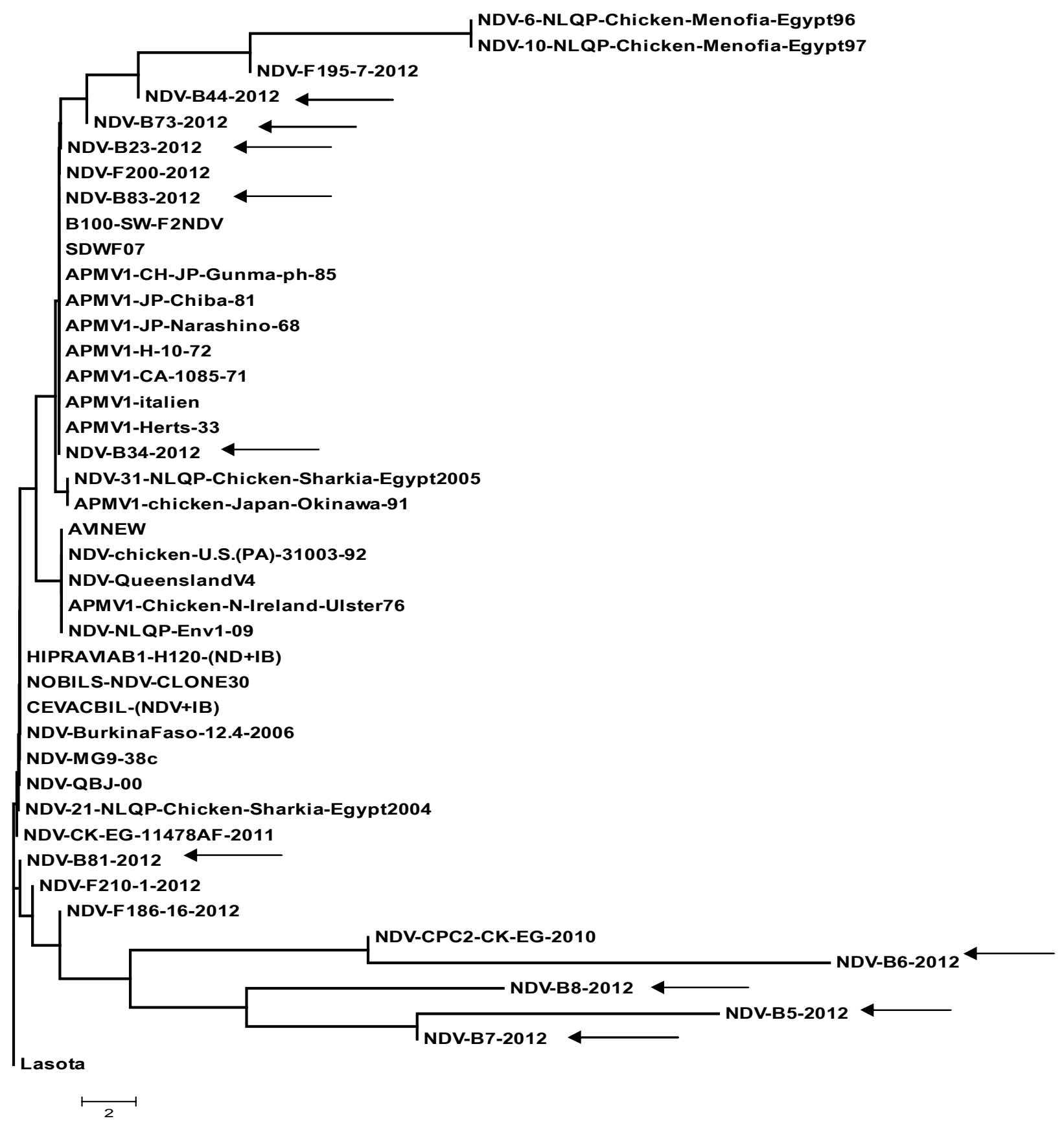

(Fig. 3): Phylogenetic analysis of F gene of the Egyptian NDV isolates in the present study 2012 in comparison to other strains.

*Note : Black arrows refer to the sequenced strains in this study.

\section{DISCUSSION}

Conventional microbiological methods are sensitive and specific, it takes considerable time (4 to 7 days) to reach a diagnosis; therefore, PCR-based detection and pathotyping assays have been developed to support/substitute for these traditional diagnostic tools and to replace animal experiments (Kant et al., 1997; Aldous et al., 2001; Creelan et al., 2002; Pham et al., 2005 and Wise et al., 2004). Real-time RTPCR can offer several advantages over standard RTPCR, such as speed and lower risk of cross contamination of clinical samples with previously amplified products In addition, the detection of the amplicon with a sequence-specific probe further confirms the nature of the target, reducing false positivity (Schweiger et al., 2000; Spackman et al., 2002; Lee and Suarez, 2004; Stone et al., 2004; Di Trani et al., 2006 and Payungporn et al., 2006). Standardized RT-PCR protocol can also be applied easily to other respiratory viruses. our results for AI virus detection by RT- PCR confirm the endemic picture of AI H5 with a percentage of $17 \%$ from total examined farms and those strains belongs to classic 
strain in Egypt and these observation agree with results of Aly et al. (2008) which recorded that the HPAI virus of subtype H5N1 was first recorded in Egypt in 2006 and since then, the disease has become endemic and still causes a significant threat to the poultry industry and humans in Egypt. Detection of two subtypes of AI, HPAI H5N1 and LPAI-H9N2 is also detected in the present study with a percentage of $3.5 \%, 17.4 \%$ from total examined respectively, and this conclusion discussed by Shortridge et al., 1998; Spackman et al., 2002; Salzberg et al.; 2007 and Xu et al., 2007 detected the presence of LPAI-H9N2 and the HPAI-H5N1 viruses have continuously cocirculated in domestic poultry in different areas. The high percent of AI H9 in this study is $83 \%$ from total positive AI cases it also reflects the low pathogenic nature of the virus which allow the silent spread of such viruses in commercial chickens and this results agree with that of (Nili and Asasi, 2002; Kim et al., 2006; Aamir et al., 2007; Naeem et al., 2007 and Park et al., 2011). Which discussed and recorded that phenomenon of silent spread of LP H9N2 in the Middle East region for several years indicated additional risk factor to the poultry industry. Although H9N2 viruses are characterized as low pathogenic avian influenza (LPAI) viruses, they may cause high morbidity and mortality Since avian H9N2 viruses are currently perceived to represent a significant threat to human health it is important to determine whether or not viruses of this subtype circulating in poultry in various parts of the world have the potential to infect people (Cameron et al., 2000). To determine the genetic relationship of H5N1, H9N2 avian influenza viruses and ND virus currently prevalent in poultry in Egypt using Phylogenicity relationship analysis of the 4 selected strains of $\mathrm{H} 5 \mathrm{~N} 1$ are highly pathogenic as well as tracking subclade 2.2.1 classical strain and these results confirmed that recorded by Arafa et al. (2012a) that recorded the presence of HPAI H5N1, and that group is prevailing mainly in village poultry and had fewer mutations compared to the originally introduced virus in 2006 Since 2009, this group has started to be transmitted back to commercial sectors. On the other hand the Phylogenetic analysis of the HA gene showed that the 4 Egyptian isolates of H9N2 in our study were resemble that isolated from Egypt in 2011 the G1-ike lineage similar to the circulating viruses in the Middle East with very close phylogeny to the Israeli viruses and these results also resemble the results obtained by Arafa et al. (2012b) when they recorded different strains of low pathogenic H9N2 in poultry sector. Currently the isolation of the causative virus using embryonated chicken eggs and its characterization by hemagglutination activity (HA)/ hemagglutination inhibition/in vivo pathogenicity assays is the standard protocol to confirm ND cases (Alexander 2004). The discrimination of a virulent (e.g., vaccine viruses) and virulent NDV strains is very important in regions practicing vaccination as a control measure against ND, especially in the context of the differential diagnosis of avian influenza (Alexander 2004). In this study we use primers specific to amplify the F gene for Newcastle indeed similar primers were used by Kant et al. (1997). To amplify the F gene sequence specifically from virulent and non-virulent strains of NDV. In this surveillance $58.5 \%$ positive cases of Virulent strains of Newcastle disease virus were detected from total positive (NDV examined farms) this high percent is agree to that mentioned by Kim et al. (2013), that the Virulent NDV can cause destructive signs in chickens all over the world. Although the current vaccines are substantially effective, they do not completely prevent infection, virus shedding and disease. All NDV isolates belong to a single serotype. Consistent with this, currently used vaccines, such as strains B1 and LaSota, are known to protect against morbidity and mortality caused by NDV isolates in different parts of the world (Cho et al., 2008). However, recent studies have suggested that NDV strains currently in circulation represent genotypes that differ from that of the vaccine strains (Miller et al., 2010).

We conclude that the active surveillance is very important to detect the co-circulated viruses within the farms as well as evaluation of viruses and genotypic characterization help in the selection of the type of vaccine used.

\section{REFERENCES}

Aamir, U.B.; Wernery, U.; Ilyushina, N. and Webster, R.G. (2007): Characterization of avian H9N2 influenza viruses from United Arab Emirates 2000-2003. Journal of Virology, 361, 45-55.

Aldous, E.W.; Collins, M.S.; McGoldrick, A. and Alexander, D.J. (2001): Rapid pathotyping of Newcastle disease virus (NDV) with fluorogenic, probes in a PCR assay. Vet. Microbiol. 80:201-212.

Alexander, D.J. (2004): Highly pathogenic avian influenza/Newcastle disease,p. 258-282. In OIE Manual of diagnostic tests and vaccines for terrestrial animals, 5th ed. Office International des Epizooties, Paris, France.

Alexander, D.J. (2007): An overview of the epidemiology of avian influenza. Vaccine,25, 5637-5644.

Aly, M.M.; Arafa, A. and Hassan. M.K. (2008): Epidemiological findings of outbreaks of disease caused by highly pathogenic H5N1 avian influenza virus in poultry in Egypt during 2006. Avian Dis. 52:269-277.

Arafa, A.; Suarez, D.; Kholosy, S.G.; Hassan, M.K.; Nasef, S.; Selim, A.; Dauphin, G.; Kim, M.; Yilma, J.; Swayne, D. and M.M. Aly, M.M. (2012a): Evolution of highly pathogenic avian influenza H5N1 viruses in Egypt indicating 
progressive adaptation. Arch. Virol. 157: 1931-1947.

Arafa, A.; Hagag, N.M.; Yehia, N.; Zanaty, A.M.; Mahmoud M. Naguib, M.M. and Nasef, S. (2012b): Effect of co-circulation of highly pathogenic avian influenza H5N1 subtype with low pathogenic H9N2 subtype on the spread of infections. Avian Dis., 56:849-857.

Ben Shabat, M.; Meir, R.; Haddas, R.; Lapin, E.; Shkoda, I. Raibstein, I., Perk, S. and Davidson, I. (2010): Development of a real-time TaqMan RT-PCR assay for the detection of H9N2 avian influenza viruses. J Virol Methods.; 168 (1-2): 72-7.

Cameron, K.R.; Gregory, V.; Banks, J.; Brown, I.H.; Alexander, D.J.; Hay, A.J. and Lin, Y.P. (2000): H9N2 subtype influenza A viruses in poultry in Pakistan are closely related to the H9N2 viruses responsible for human infection in Hong Kong. Virology 278, 36-41.

Cho, SH.; Kwon, HJ.; Kim, TE.; Kim, JH. and Yoo, HS. (2008): Characterization of a recombinant Newcastle disease vaccine strain. Clin Vaccine Immunol 15: 1572-1579. doi:10.1128/CVI. 00156-08.PubMed: 18768673.

Creelan, J.L.; Graham, D.A. and McCullough, S.J. (2002): Detection and differentiation of pathogenicity of avian paramyxo virus serotype 1 from field cases with one-step reverse transcriptase-polymerase chain reaction. AvianPathol.31: 493-499.

Di Trani, L.; Bedini, B.; Donatelli, I.; Campitelli, L.; Chiappini, B.; De Marco, M.A.; Delogu, M.; Buonavoglia, C. and Vaccari, G. (2006): A sensitive one-step realtime PCR for detection of avian influenza viruses using a MGB probe and an internal positive control. BMC Infect Dis 6: 87.

Duvvuri, V.R.; Duvvuri, B.; Cuff, W.R.; Wu, G.E. and $W u$, J. (2009): Role of positive selection pressure on the evolution of H5N1 hemagglutinin. Genomics Proteomics Bioinformatics (7): 47-56.

El-Zoghby, E.F.; Arafa, A.; Hassan, M.K.; Aly, M.M.; Selim, A.; Kilany, W.H.; Selim, U.; Nasef, S.; Aggor, M.G.; Abdelwhab, E.M. and Hafez, M.H. (2012): Isolation of H9N2 avian influenza virus from bobwhite quail (Colinusvirginianus) in Egypt. Arch Virol. DOI10.1007/s00705-012-1269-z.

Kant, A.; Koch, G.; Van Roozelaar, D.; Balk, F. and TerHuurne, A. (1997): Differentiation of virulent and non-virulent strains of Newcastle disease virus within 24 hours by polymerase chain reaction. Avian Pathol.26: 837-849.

Kim, J.A.; Cho, S.H.; Kim, H.S. and Seo, S.H. (2006): H9N2 influenza viruses isolated from poultry in Korean live bird markets continuously evolve and cause the severe clinical signs in layers. Veterinary Microbiology, 118,169-176.
Kim, S.H.; Wanasen, N.; Paldurai, A.; Xiao, S.; Peter L.; Collins, P.L.; Siba, K. and Samal, S.K. (2013): Newcastle Disease Virus Fusion Protein Is the Major Contributor to Protective Immunity of Genotype-MatchedVaccine., Vol8 (8): e74022.

Lee, M.S.; Chang, P.C.; Shien, J.H.; Cheng, M.C. and Shieh, H.K. (2001): Identification and subtyping of avian influenza viruses by reverse transcription-PCR. J. Virol Methods 97, $13-22$.

Lee, C.W. and Suarez, D.L. (2004): Application of real-time RT-PCR for thequantitation and competitive replication study of $\mathrm{H} 5$ and $\mathrm{H} 7$ subtype avian influenza virus. J. Virol Methods 119: 151-158.

Miller, P.J.; Decanini, E.L. and Afonso, C.L. (2010): Newcastle disease: evolution of genotypes and the related diagnostic challenges. Infect Genet Evol 10: 26-35. doi: 10.1016/j.meegid. 2009.09.012. PubMed: 19800028.

Mohamed, M.H.; Kumar, S.; Paldurai, A.; Megahed, M.M.; Ghanem, I.A.; Lebdah, M.A. and Samal, S.K. (2009): Complete genome sequence of a virulent Newcastle disease virus isolated from an outbreak in chickens in Egypt. Virus Genes, 39: 234-237.

Munch, M.; Nielsen, L.P.; Handberg, K.J. and Jorgensen, P.H. (2001): Detection and subtyping (H5 and $\mathrm{H} 7$ ) of avian type A influenza virus by reverse transcription-PCR and PCR-ELISA. Arch Virol 146, 87-97.

Naeem, K.; Siddique, N.; Ayaz, M. and Jalalee, M.A. (2007): Avian influenza in Pakistan: outbreaks of low- and high-pathogenicity avian influenza in Pakistan during 2003-2006. Avian Diseases, 51(1 Suppl), 189-193.

Nili, H. and Asasi, K. (2002): Natural cases and an experimental study of H9N2 avian influenza in commercial broiler chickens of Iran. Avian Pathology, 31, 247-252.

OIE (2008): Manual of Diagnostic tests and Vaccines for Terrestrial Animals,

OIE (2012): Manual of Diagnostic tests and Vaccines for Terrestrial Animals, Capter 2.3.4.

Park, K.J.; Kwon, H.I.; Song, M.S.; Pascua, P.N.; Baek, Y.H.; Lee, J.H.; Jang, H.L.; Lim, J.Y.; Mo, I.P.; Moon, H.J.; Kim, C.J. and Choi, Y.K. (2011): Rapid evolution of low 379 pathogenic H9N2 avian influenza viruses following poultry vaccination programmes. J. Gen. Virol. 92, 36-50.

Payungporn, S.; Chutinimitkul, S.; Chaisingh, A.; Damrong wantanapokin, S.; Buranathai, C.; Amonsin, A.; Theamboonlers, A. and Poovorawan, Y. (2006): Single step multiplex real-time RT-PCR for H5N1 influenza A virus detection. J Virol Methods 131:143-147.

Perk, S.; Golender, N.; Banet, C.; Shihmanter, E.; Pirak, M.; Tendler, Y.; Lipkind, M. and 
Panish, A. (2009): Phylogenetic analysis of hemagglutinin, neuraminidase, and nucleoprotein genes of H9N2 avian influenza viruses isolated In Israel during the 2000-2005 epizootic. Comparative Immunology, Microbiology and Infectious Diseases. 32, 221-238.

Pham, H.M.; Konnai, S.; Usui, T.; Chang, K.S.; Murata, S.; Mase, KOhashi, M. and Onuma, M. (2005): Rapid detection and differentiation of Newcastle disease virus by real-time PCR with melting-curve analysis. Arch. Virol. 150: 2429-2438.

Salzberg, S.L.; Kingsford, C.; Cattoli, G.; Spiro, D.J.; Janies, D.A.; Aly, M.M.; I. Brown, H.; Couacy-Hymann, E.; De Mia, G.M.; Dung do, H.; Guercio, A.; Joannis, T.; Maken Ali, A.S.; Osmani, A.; Padalino, I.; Saad, M.D.; Savic, V.; Sengamalay, N.A.; Yingst, S.; Zaborsky, J.; Zorman-Rojs, O.; Ghedin, E. and Capua, I. (2007): Genome analysis linking recent European and African influenza (H5N1) viruses. Emerg. Infect. Dis. 13: 713-718.

Schweiger, B.; Zadow, I.; Heckler, R.; Timm, H. and Pauli, G. (2000): Application of a fluorogenic PCR assay for typing and subtyping of influenza viruses in respiratory samples. J ClinMicrobiol 38: 1552-1558.

Shortridge, K.F.; Zhou, N.N.; Guan, Y.; Gao, P.; Ito, T.; Kawaoka, Y.; Kodihalli, S.; Krauss, S.; Markwell, D.; Murti, K.G.; Norwood, M.; Senne, D.; Sims, L.; Takada, A. and Webster, R.G. (1998): Characterization of avian H5N1 influenza viruses from poultry in Hong Kong. Virology 252, 331-342.
Slomka, M.J.; Pavlidis, T.; Banks, J.; Shell, W.; McNally, A.; Essen, S. and Brown, I.H. (2007): Validated H5 Eurasian real-time reverse transcriptase- polymerase chain reaction and its application in H5N1 outbreaks in 20052006. Avian Dis 51: 373-377.

Spackman, E.; Senne, D.A.; Myers, T.J.; Bulaga, L.L.; Garber, L.P.; Perdue, M.L.; Lohman, K.; Daum, L.T. and Suarez, D.L. (2002): Development of a real-time reverse transcriptase PCR assay for type A influenza virus and the avian $\mathrm{H} 5$ and $\mathrm{H} 7$ hemagglutinin subtypes. J Clin Microbiol 40: 3256-3260.

Starick, E.; Romer-Oberdorfer, A. and Werner, $O$. (2000): Type- and subtype-specific RT-PCR assays for avian influenza A viruses (AIV). J. Vet Med B Infect Dis Vet Public Health 47, 295-301.

Stone, B.; Burrows, J.; Schepetiuk, S.; Higgins, G.; Hampson, A.; Shaw, R. and Kok, T. (2004): Rapid detection and simultaneous subtype differentiation of influenza A viruses by real time PCR. J Virol Methods 117: 103-112.

Wise, M.G.; Suarez, D.L.; Seal, B.S.; Pedersen, J.C.; Senne, D.A.; King, D.J.; Kapczynski, D.R. and Spackman, E. (2004): Development of a realtime reverse-transcription PCR for detection of Newcastle disease virus RNA in clinical samples. J. Clin. Microbiol.42: 329-338.

Xu, K.M.; Smith, G.J.; Bahl, J.; Duan, L.; Tai, H.; Vijaykrishna, D.; Wang, J.; Zhang, J.X.; Li, K.S. and Fan, X.H. (2007): The genesis and evolution of $\mathrm{H} 9 \mathrm{~N} 2$ influenza viruses in poultry from southern China, 2000 to 2005. J. Virol 2007, 81:10389-10401.

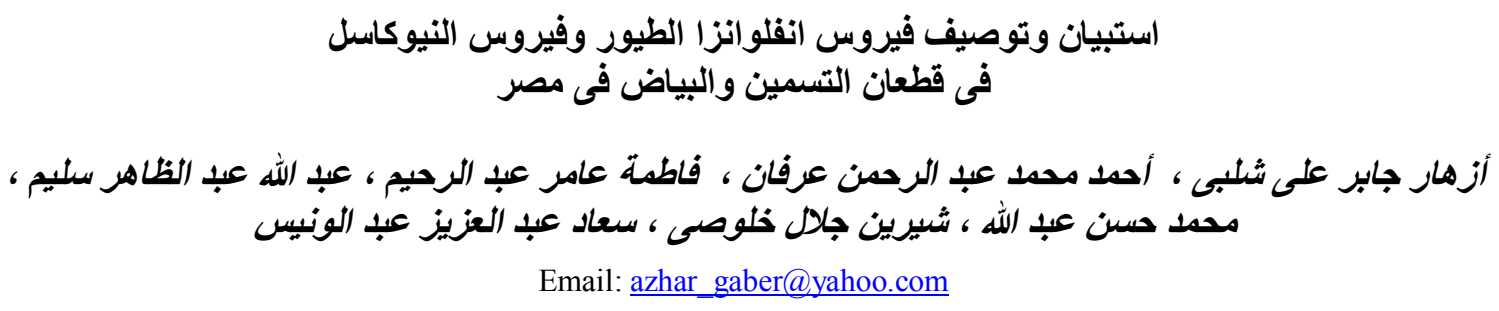

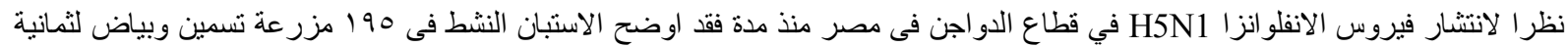

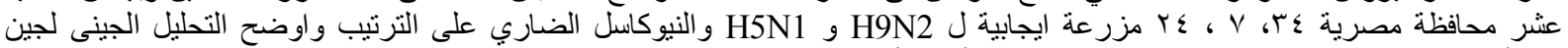

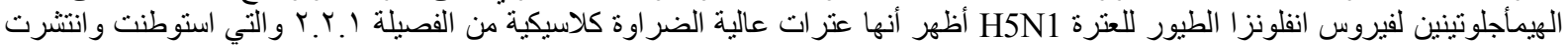

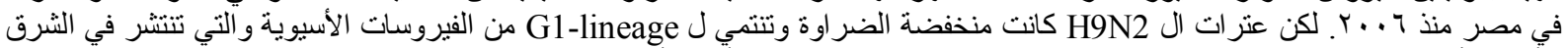

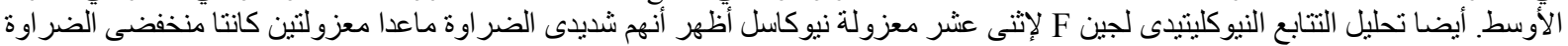

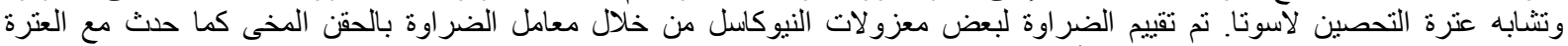

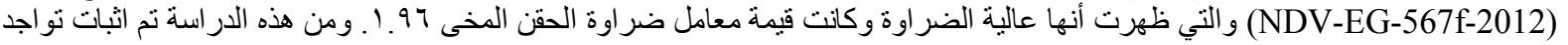

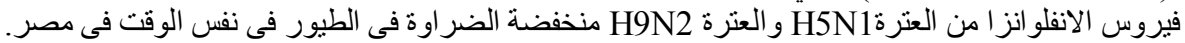

